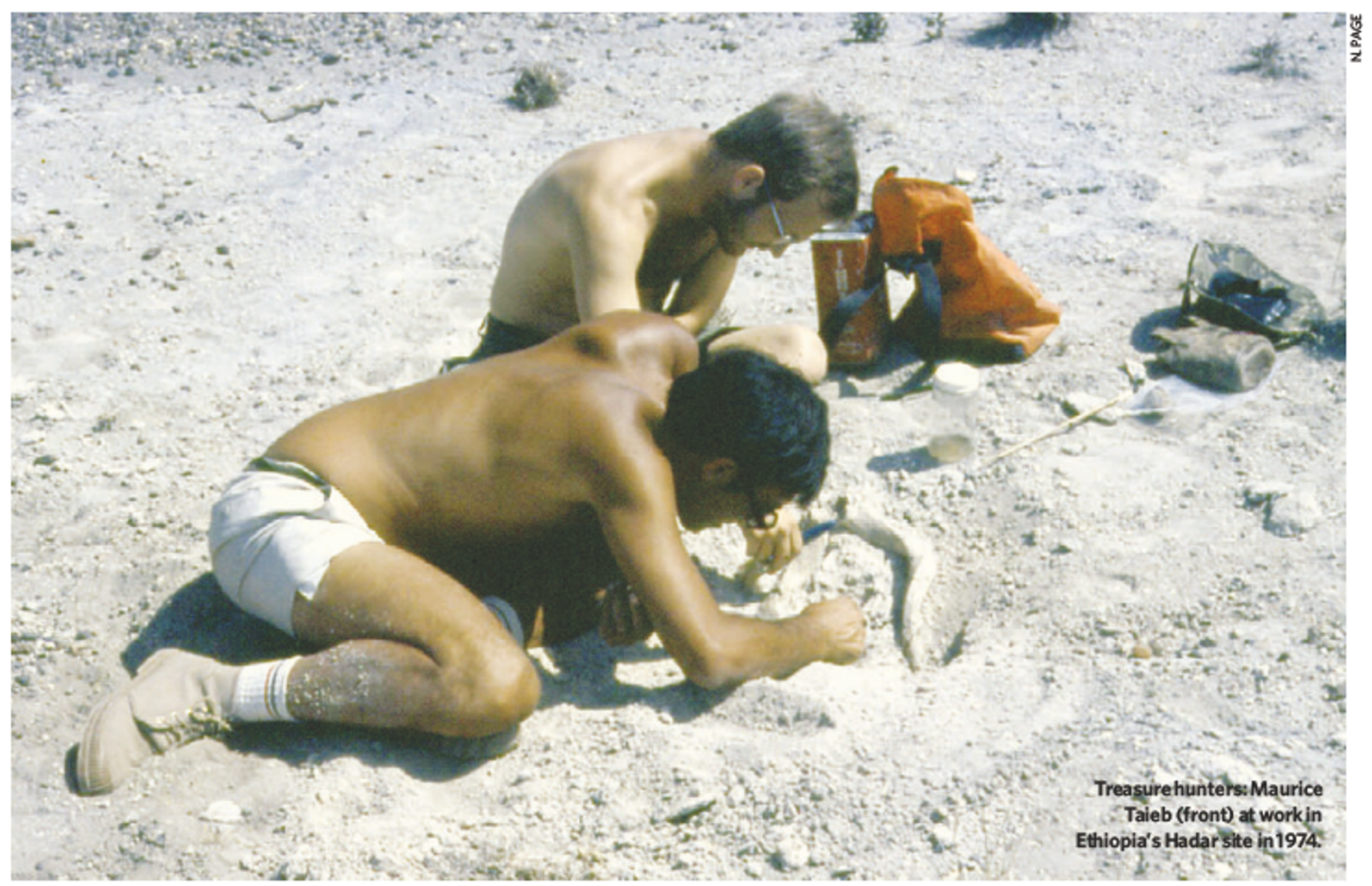

\title{
THE HISTORY MAN
}

\section{Maurice Taieb laid the groundwork for the discovery of Lucy, the most famous fossil human ancestor. Rex Dalton meets the Tunisian-born geologist who prefers the desert to the limelight.}

t was the type of desert encounter where only someone like Maurice Taieb wouldn't flinch. In the shimmering afternoon heat of the Ethiopian desert, four tribesmen materialized across the river from Taieb's geology field camp. Along with their machine guns they carried millennia of tribal animosities, the sort of hatred that can erupt in deadly skirmishes over grazing rights or livestock.

Taieb recognized the visitors as Issa tribesmen, prowling the lands of their rivals, the Afar. His Afar tribal guards and workers recognized it too, and melted away as quickly as the intruders arrived. Unarmed, Taiebturned to his few remaining colleagues and said: "Let's invite them for tea."

They sipped and bantered until the Issa left, melting back into the desert glare as silently as they had come. Taieb had manoeuvred his way through another dangerous interlude.

"Fearless" is how US palaeoanthropologist Tim White, of the University of California, Berkeley, describes Taieb, a geological legend for his exploration of the Afar region of eastern Ethiopia. It is such a dangerous and hard place that only a handful of early-twentieth-century researchers had attempted to explore there. When Taieb started in 1966, he had the rich sediments nearly to himself. Eventually, his work would help lead palaeoanthropologists My passion was to do research

in Ethiopia, working with young Ethiopian scientists." -

\section{Maurice Taieb} fossils of our earliest relatives.

Roaming the valley of the Awash River by Land Rover or donkey, Taieb picked his way through eroding gullies. Following a trail of snail fossils and encouraged by an elephant tooth, in 1968 he discovered the fossil-rich site now famous as Hadar. There, in 1974, colleagues would discover Lucy - the 3.3-million-year-old hominid that came to symbolize a new era of palaeoanthropology ${ }^{1}$. Lucy - named after the Beatles song "Lucy in the Sky with Diamonds" but formally known as Australopithecus afarensis - walked upright like modern humans but still displayed primitive characteristics ${ }^{2}$.
In this issue of Nature, researchers continue Taieb's legacy with a report on a nearly complete skeleton of a three-year-old $A$. afarensis ${ }^{3,4}$. From newly explored sediments just south of the Lucy site, Zeresenay Alemseged, an Ethiopian researcher at the Max Planck Institute for Evolutionary Anthropology in Leipzig, Germany, and his colleagues provide a stunning view of hominid evolution.

With this three-year-old A. afarensis female, researchers can now see in a near-complete skeleton what a mosaic of evolution the species is - the upper limbs have characteristics of gorilla or chimp, whereas the lower limbs are made for walking upright like modern humans.

\section{Mother lode}

Thanks to the Hadar site, researchers arguably have more bones of Lucy's species than of any other early hominid. At Hadar, a sedimentary layer at least 200 metres thick preserves A. afarensis history between about 3 million and 3.5 million years ago. The annual rains have exposed hundreds of fossils, of dozens of individual hominids. This fossil library, with today's new additions, allows researchers to do 
crucial comparative analyses as with no other human ancestor.

Beyond Hadar, Taieb has helped piece together the complex geological picture of the Afar region, which yields hominid specimens back to 6 million years old ${ }^{5}$. With such a pedigree, he should be a big name in science. But he's barely known outside his field.

In the four decades since Taieb first went into the field, palaeoanthropologists have had their share of publicity. Some work the book and media circuit like most scientists do a library. Taieb disdains such hype-mongering; dismissing mention of headline seekers with the sweep of a hand clutching his ever-present cigarette. He seems to prefer the respect of the desert tribesmen; the headlines he wants to see are for the Africans he helped to train. "Mypassion was to do research in Ethiopia, working with young Ethiopian scientists so they could do the work, ${ }^{\text {n }}$ he says.

Taieb also stands out in a field where squabbles over credit for discoveries and permits to work at key sites are common. " $\mathrm{He}$ is a role model for all palaeoanthropology - an unselfish individual who invited anyone to his rich Hadar site," says geochronologist Giday WoldeGabriel of the Los Alamos National Laboratory in New Mexico. "He shows how people can work together for the betterment of science."

\section{Summit meeting}

z And he likes getting people together. In June, the 71-year-

old Taieb threw a scientific

$\checkmark$ party at the CEREGE Mediterranean European Laboratory outside the French city of Marseilles, where he has been a researcher for nearly 30 years. He invited about 40 scientists to a three-day conference to reflect on Lucy's place in evolution.

It mixed badkroom people with spotlight seekers, eminent Europeans with Africa's finest young rock hounds. And the Ethiopian scientists were front and centre, moderating key sessions. Only Taieb, skilled in scientific as well as desert diplomacy, could bring together such a crowd. Indeed, at a concluding dinner, Taieb was embraced simultaneously by two pillars of palaeoanthropology: White and Donald Johanson, now of Arizona State University in Tempe, who led the crew that found Lucy. Former collaborators, White and Johanson now barely speak to each other because of earlier bitter disagreements over research style and conduct.

In his lecture at CEREGE, Johanson recalled how, as a 27-year-old novice, Taieb "bubbling with enthusiasm" told him: "If you want to find fossils, you should come to the Afar." It is a place where three tectonic plates of Earth's crust come together, exposing sediments of just the right age to contain human ancestors. At

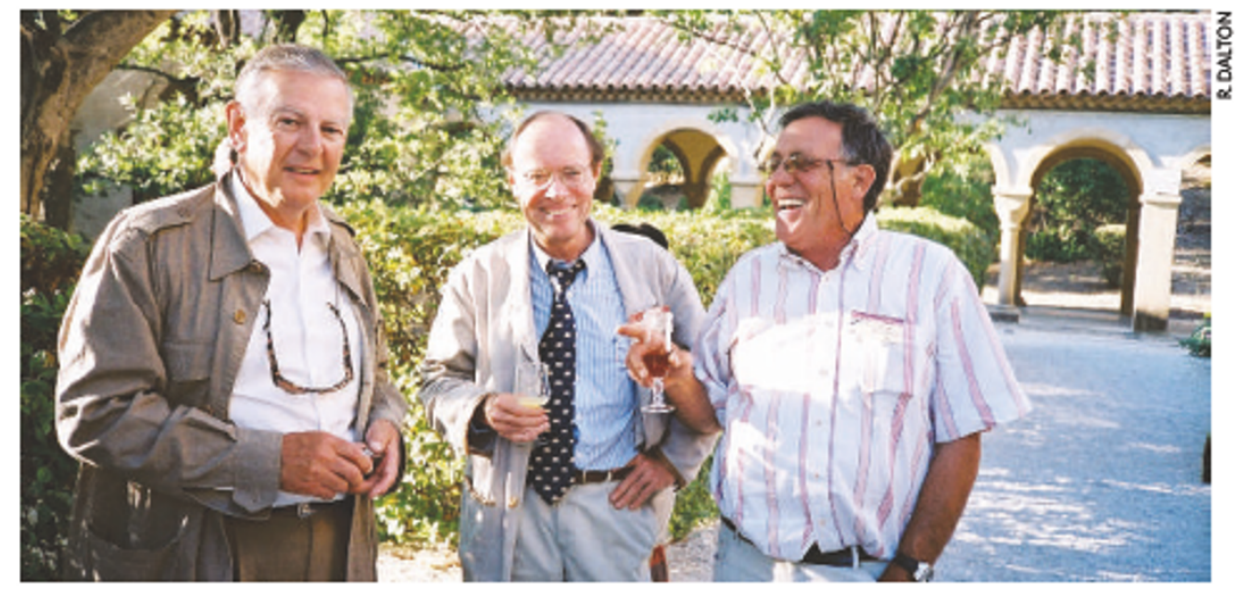

Don Johanson (left) and Tim White (centre) rarely speak, but Maurice Taieb can get them together.

the time, new dating techniques had greatly improved scientists' ability to pin down the ages of sediments and their contents. In short, it was the perfect time and place for a desert aficionado such as Taieb to start working.

Born in Tunisia, to a Tunisian father and a French mother, Taieb began his lifelong love of the African outback travelling with a merchant uncle selling goods to Bedouin on the outskirts of Tunis. He eventually madehis way to France, receiving his doctorate from the University of Paris VI in 1974, with a thesis on the geology of the Awash River basin.

Decades after the French and Italians cut roads from Djibouti to Addis Ababa, Taieb followed those trails through the Afar. Again and again he circled huge areas cut by gullies and ridges. The treks gave him a vast knowledge of the landscape and its peoples; around campfires today, Afar elders still ask with interest after Maurice.

For many of Taieb's early years in the field, the biggest worries were maintaining fuel and water supplies. It wasn't until 1993 when, in what he recalls as his most dangerous moment, he faced down the Issa and asked them to tea. After that incident, he and his two companions - a student and an interpreter - lay away from their camp at night, ready to bolt at any sign of attack. Indeed, the area soon turned violent; a day later, a team sent by French officials to escort them out drove through a roadblock on an isolated path a few hours from Hadar. Panicked militia riddled the truck with bullets, killing an Ethiopian cultural officer and seriously injuring two others.

For anyone, the Afar was a dangerous place. The Dergue government, backed by the Soviet Union, came to power in the mid-1970s; for most of the 1980 s, all field research was shut down by the political cimate. Yet some of the old hands of Ethiopian anthropology think that research may not have been as limited had certain people listened to Taieb's advice on what became known as "the grave-robbing incident".

In the late 1970 s, while preparing a book about Lucy's discovery ${ }^{6}$, Johanson wrote about digging the femur of a modern Afar tribesman out of a rock-covered cairn, in order to compare it with a fossilized hominid knee bone later determined to be $A$. afarensis. When Taieb saw this vignette in an unpublished manuscript of the book, he says he objected vehemently, arguing that it would anger the Ethiopian authorities. His warnings were ignored. Today, Johanson will not discuss this episode. Becoming agitated when asked about these events, he denied hearing such advice.

When the book was published in 1981, jealous competitors highlighted the passage for Ethiopian officials. As predicted, they were furious. Johanson's team, on which Taieb was the geologist, and others didn't get their excavation permits back for nearly a decade.

When Johanson finally secured permits again in 1991, Taieb was dropped from the team. ${ }^{\alpha} \mathrm{He}$ forgot to send the elevator back down, Taieb was to say years later. Some Ethiopian scientists tried to help Taieb win access to another key spot, but to no avail. He has since returned to the Afar only to help a student complete his thesis.

"I have no hard feelings," says Taieb. "It is life. I now have many letters of support from young Ethiopian scientists; this is my pleasure." And he invited Johanson to his June symposium, where the famous palaeoanthropologist spoke highly of his former geologist colleague. During cocktails before the final dinner at a historic French estate, the pair ventured off together to speak of old times. For the observing Ethiopian scientists, who had learned from Taieb in lab and field, it was another chance to mark his place in evolutionary history.

Rex Dalton writes for Nature from San Diego.

1. Johanson, D.C.\& Taieb, M. Nature 260,293-297(1976).

2. Johanson, D.C.et al. Kirtlandia 28,1-14 (1978).

3 Alemseged, Z. et al. Nature 443, 296-301(2006).

4. Wood, B. Nature 443, 278-281 (2006).

5. White, T. D.et al. Nature 440,883-889 (2006).

6. Johanson, D.C.\& Edey, M. Lucy: The Beginings of Mankind (Simon\& Schuster, 1981). 